\title{
Bioeconomic Analysis of Resource Utilization of Flying Fish (Hyrundicthys oxycephalus) in the Makassar Strait, South Sulawesi, Indonesia
}

\author{
Kasri $^{1}$, Aris Baso ${ }^{2}$, Hamzah Tahang ${ }^{2}$ \\ ${ }^{1}$ Student of Master Degree Fisheries Science, Faculty of Marine and Fisheries Science, Hasanuddin University, Perintis Kemerdekaan St \\ Km 10, Makassar 90245, Indonesia \\ ${ }^{2}$ Department of Fisheries Science, Faculty of Marine and Fisheries Science, Hasanuddin University, Perintis Kemerdekaan St Km 10, \\ Makassar 90245, Indonesia \\ Email: kasrimuhammad219@gmail.com
}

\begin{abstract}
This study aims to analyze the bioeconomic value of the use offlying fish in the Makassar Strait waters. The study was conducted in November 2018-March 2019 which took place in Takalar District. Data collection techniques are conducted by interview, observation, questionnaire and literature study. The research method in this study is the survey method. The sampling technique in this study used a purposive sampling technique by taking a sample of 36 samples of flying fish business. Data analysis using the static and optimal dynamic bioeconomic formula with the help of Microsoft Excel and Maple 18. Software. The results showed that the actual conditions of the use of flying fish in the Strait Waters have experienced overfishing, both biologically and economically with the actual production amount of 1,604 tons, maximum production in the management regime of MSY (Maximum Sustainable Yield) with a total production of 2,545 tons, maximum production in the MEY (Maximum Economic Yield) management regime with a total production of 2,538 tons with an economic rent of 14,687,087,983 IDR.

Keywords - Bioeconomic, Utilization, Flying Fish, Makassar Strait
\end{abstract}

\section{INTRODUCTION}

The increasing population increase has led to increased use of funds from time to time. This condition requires an agreement on resource management and exploitation will ultimately resolve the balance of the Environment. Therefore, resources must consider the technology used and the carrying capacity of the environment or preservation. Economic pressure has become very dominant in applying coastal communities. Sustainability of the Fisheries and Marine Fund has not received attention in meeting market demand for fish where demand has increased along with the increasing population of the world.

Even though fishery resources are classified as renewable resources, if they are not managed properly, there is a possibility that there will be a decrease in both the quality and quantity of the stock or even the worst is the occurrence of scarcity or extinction. According to [1] that there has been a significant increase in the exploitation of fish resources from 1995-2004. The exploitation of the resource in question has exceeded sustainable production and in some regions of Indonesia, overfishing has occurred, fishing, at least economic overfishing is characterized by high use of inputs, but not followed by proportional increases in output and returns.
The exploitation of flying fish fisheries, especially their eggs, it is feared that in the future there will be a decline in flying fish stocks. This trend has begun to be identified, namely by decreasing the number of flying fish and flying fish eggs, and decreasing the average length of caught flying fish. [2].

This condition resulted in the condition of flying fish resources began to experience a decline in production from year to year, due to the exploitation of the mother of flying fish and flying fish eggs on a large scale and continuously. The impact of externalities produced not only affects the ecosystem but also affects the socio-economic conditions of fishing communities in the future. Seeing the existence of flying fish resources is pride as an icon of fisheries in the Makassar Strait will disappear as well as the presence of endemic fish in Sumatran waters such as terubuk fish. The bioeconomic approach is a combination of aspects of biology, technology, and economics [3][4].

Research on bioeconomic is still limited in South Sulawesi, namely Mackerel Indians [5], Scad Indians [6], Flying Fish [7] in the Makassar Strait and Flores sea, (Petersen, et. al, 2011), Bioeconomic of Utilizing Grouper (Plectropomus leopardus) in Selayar Islands Regency [9], and Bioeconomic of Coral Grouper in the Spermonde Islands [10]. The bioeconomic model approach to marine fisheries 
resources have been recommended by FAO, because of the many uncertainty factors in fisheries management. [11]. This study focuses on cases of catching flying fish economic value and increasing market demand which causes the exploitation of these fish to increase every year. Exploitation on a large scale and continuously will have an impact on stock conditions which will ultimately have an impact on fishermen's income and fishermen's losses. The purpose of this study was to analyze the bioeconomic value and efforts to the actual use of flying fish (Hyrundicthys oxycephalus) in the Makassar Strait waters.

\section{RESEARCH METHODS}

\subsection{Time and Place}

This research was conducted from November 2018 to April 2019. The place of this research was conducted in Takalar District in South Galesong District. Location determination is done intentionally because there is a flying fishing business unit in this sub-district that specifically catches flying fish.

\subsection{Data collection technique}

Data collection is done using interviews, observations, questionnaires and literature studies.

\subsection{Research Method}

The research method is primarily a scientific way to get data with specific purposes and uses. To achieve these objectives, a method that is relevant to the goals to be achieved is needed. The method used in this study is the survey method. According to [12] the survey method is "Research conducted using questionnaires as a research tool carried out in large and small populations, but the data studied is data from samples taken from the population, so that relative events, distribution, and relationships between variables, sociological and psychological ".

\subsection{Sampling Technique}

Sampling for research according to [13], if the subject is less than 100 people, all should be taken, if the subject is large or more than 100 people can be taken $10-15 \%$ or 20 $25 \%$ or more. Based on data from the Department of Maritime Affairs and Fisheries, the number of flying fish businesses in South Galesong is 104. Whereas in the District of North Galesong and South Galesong there were no fishing businesses that specifically caught flying fish but were more focused on catching flying fish eggs. So from that researcher took a sample of $35 \%$ of the population, which is about 36 samples of the fly fishing business.

\subsection{Data Analysis}

2.5.1. Catch per Unit Effort (CPUE)

After the production data and efforts (input or effort) are arranged in a time series according to the type of fishing gear, the next step is to find the catch per unit effort (CPUE). According to [14], the calculation of CPUE aims to determine the abundance and level of utilization of fisheries resources in a particular water area. The CPUE value can be denoted as follows:

$\mathrm{CPUE}_{t}=\frac{\text { Catch }_{1}}{\text { Effort }_{1}}$

Where :

CPUE $_{t}$ : catches per fishing effort in year $\mathrm{t}$

Catch $_{1}:$ catch in the t-year

\subsubsection{Standardization of Fishing Gear}

Standardization of fishing gear aims to homogenize different units of effort, so it can be assumed that the effort to capture a type of fishing gear is the same as standard fishing gear. The standard fishing gear is based on the amount of the catch obtained and the magnitude of the value of the fishing power index (FPI) with the input (effort) of a standardized tool.

$\mathrm{E}_{\text {std }}=\mathrm{Y}_{\text {tot }} / \mathrm{CPUE}_{\text {std }}$

Dimana :

Estd : Standardized Fishing Efforts

CPUE $_{\text {std }}$ : CPUE standard capture tool

Ytot : CPUE is the standard

\subsubsection{Estimated Biological Parameters}

Biological parameters include the water carrying capacity constants (K), natural growth constants (r), technological parameters (q). While the economic parameters include the cost per fishing effort (c/p), the price of flying fish per unit, the catch $(p)$, and the discount rate. There are several approaches in estimating biological parameters, but in this study the estimation model is CYP (Clark, Yoshimoto and Pooley) with the approach and development of the formula model [15] and [16], systematically the equation is written as follows: [17]

$$
\begin{aligned}
\operatorname{Ln}\left(U_{t+1}\right) & =\frac{2 r}{(2+r)} \operatorname{Ln}(q, K)-\frac{(2-r)}{(2+r)} \operatorname{Ln}\left(U_{t}\right)- \\
& \frac{q}{(2+r)}\left(E_{t}+E_{t+1}\right) \ldots \ldots \ldots \ldots \ldots \ldots \ldots \ldots \ldots \ldots \ldots
\end{aligned}
$$

Where :

$\mathrm{U}_{\mathrm{t}+1}:$ CPUE at time $\mathrm{t}+1$

$\mathrm{U}_{\mathrm{t}}:$ CPUE at time $\mathrm{t}$

$\mathrm{E}_{\mathrm{t}}$ : Effort at time $\mathrm{t}$

$\mathrm{E}_{\mathrm{t}+1}$ : Effort at time $\mathrm{t}+1$

$\beta_{0}$ : intercept coefficient regression results 
$\beta_{1}$ : variable $X$ coefficient 1 regression results

$\beta_{2}$ : variable $X$ coefficient 2 regression results

\subsubsection{Estimated Economic Parameters}

Economic parameters include estimated input costs, estimated capture output prices and the level of resource cuts. Catching costs or estimation of input costs obtained from primary data which is then made data series of annual capture costs using the formula:

$\mathrm{c}=\sum c_{i} / n_{1}$

Where :

c : Average catching costs (IDR) per year

$c_{i}$ : Cost catch per effort, respondents to $-\mathrm{i}$

$\mathrm{n}_{1}:$ Number of respondents

Output price estimation is obtained from primary data which is then made the real sales price data series in the year with the formula: [17]

$\mathbf{p}=\sum p_{i} / n_{2}$

Where :

$\mathrm{p}=$ Average price of catch per $\mathrm{kg}$

$\mathrm{p}_{\mathrm{i}}=$ Average price in the season

$\mathrm{n}_{2}=$ Number of seasons (peak, normal, famine)

Parameter of the level of pieces of flying fish resources

(d) using equations [3] :

$d=\ln (1+i)$

Where :

i : investment interest rate - inflation rate

$\mathrm{d}$ : discount rate of resources

\subsubsection{Bioeconomic Analysis}

The output of the bioeconomic model includes optimal stock $(\mathrm{X} *)$, optimal catch $\left(\mathrm{Y}^{*}\right)$ and optimal fishing effort $(\mathrm{E} *)$ which is assumed by using the equation:

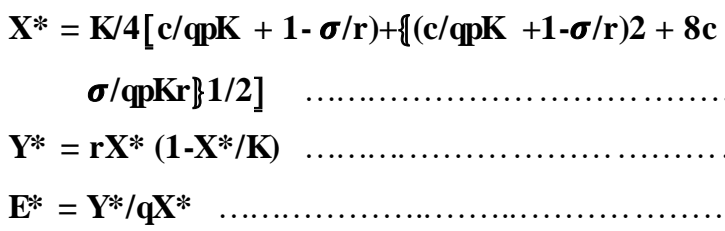

$\mathbf{Y}^{*}=\mathbf{r} \mathbf{X}^{*}\left(1-\mathbf{X}^{*} / \mathrm{K}\right)$

$\mathbf{E}^{*}=\mathbf{Y}^{*} / \mathbf{q} \mathbf{X}^{*}$

Where :

$\mathrm{K}$ : Environmental carrying capacity

c : The cost of catching flying fish

$\mathrm{p}$ : The price of flying fish per kilogram

$\mathrm{r}:$ Intrinsic growth

$\mathrm{q}$ : capture power coefficient and flying fish gear

$\boldsymbol{\sigma}:$ discount rate of resources
2.5.6. Maximum Sustainable Yield (MSY)

As a comparison, MSY, MEY and Open Access potential calculations are carried out. Calculation of the Maximum Sustainable Yield (MSY) model uses the equation:

$$
\begin{aligned}
& \mathrm{E}_{\mathrm{MSY}}=\frac{r}{2 q} \\
& \mathrm{Y}_{\mathrm{MSY}}=\frac{\mathrm{Kr}}{4} \\
& \mathrm{X}_{\mathrm{MSY}}=\frac{\mathrm{K}}{2}
\end{aligned}
$$

Where :

EMSY : Efforts to capture MSY's condition

$Y_{M S Y}:$ Catch of MSY condition

$\mathrm{X}_{\mathrm{MSY}}$ : Optimal stock estimation of MSY conditions

\subsubsection{Maximum Economic Yield (MEY)}

Assuming that the demand curve is perfectly elastic, the rent of fisheries resources based on the Maximum Economic Yield (MEY) value is obtained by using the following equation:

$$
\begin{aligned}
& \mathrm{E}_{\mathrm{MEY}}=\frac{r}{2 q}\left(1-\frac{c}{p q K}\right) \ldots \ldots \ldots \ldots \ldots \ldots \\
& \mathrm{Y}_{\mathrm{MEY}}=\frac{r K}{4}\left(1+\frac{c}{p q K}\right)\left(1-\frac{c}{p q K}\right) \\
& \mathrm{X}_{\mathrm{MEY}}=\frac{K}{2}\left(1+\frac{c}{p q K}\right) \ldots \ldots \ldots \ldots \ldots
\end{aligned}
$$

Where :

EMEY : Efforts to capture MEY's condition

YMEY : Catch of MEY condition

$\mathrm{X}_{\mathrm{MEY}}$ : Optimal stock estimation of MEY conditions

\subsubsection{Open Access (OA)}

The level of effort under open access conditions (open access)

$$
\begin{aligned}
\mathrm{E}_{\mathrm{OA}} & =\frac{r}{q}\left(1-\frac{c}{K p q}\right) \\
\mathrm{Y}_{\mathrm{OA}} & =\frac{r c}{p q}\left(1-\frac{c}{K p q}\right) \\
\mathrm{X}_{\mathrm{OA}} & =\frac{c}{p q}
\end{aligned}
$$

Where:

EOA : Efforts to capture OA's condition

$\mathrm{Y}_{\mathrm{OA}}$ : Catch of OA condition

XOA : Optimal stock estimation of OA conditions 
3.1. Flying Fish Production

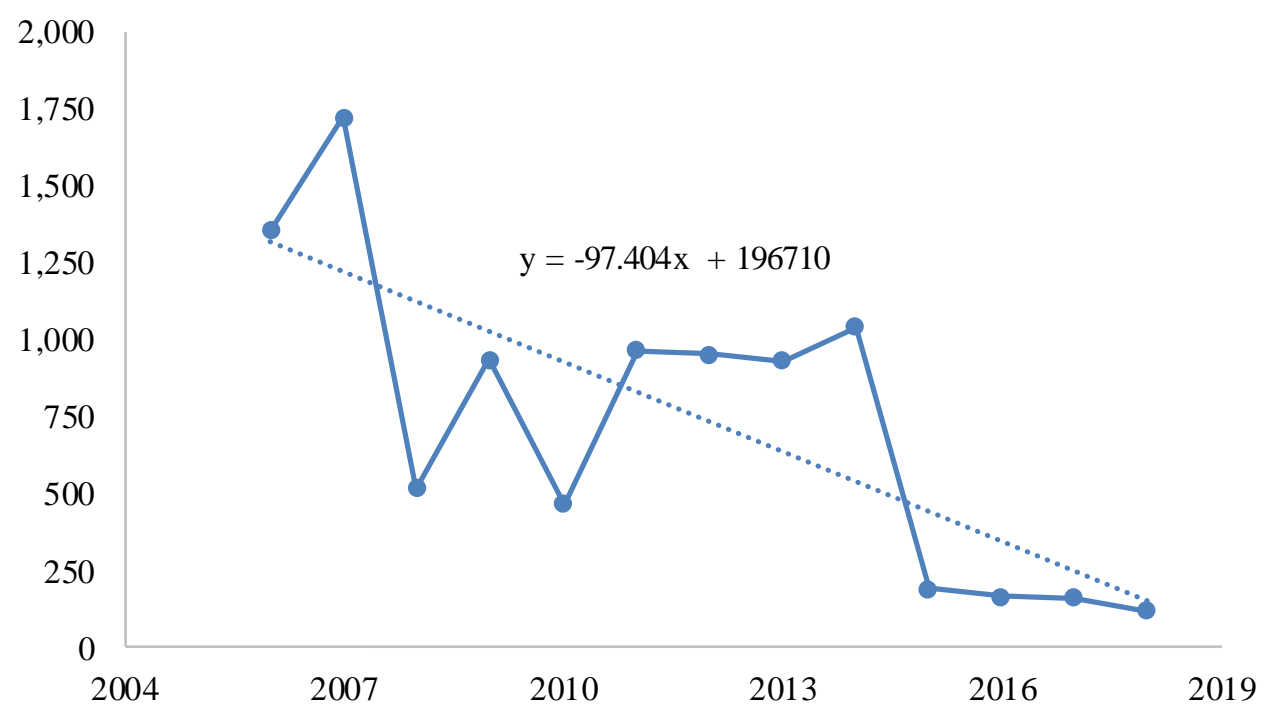

Fig.1: Production of Flying Fish in the Makassar Strait in 2006-2018

The production of flying fish in the Makas sar Strait waters is very fluctuating. However, if you look at the data carefully, the number of flying fish production in the Makas sar Strait waters tends to decrease from year to year, especially in 2008, starting from $1,722.50$ tons, it experienced a very large decline in production to 515.00 tons. The same thing happened from 2015 until 2018, a significant decrease of $73 \%$.

\subsection{Flying Fish Catching Efforts}

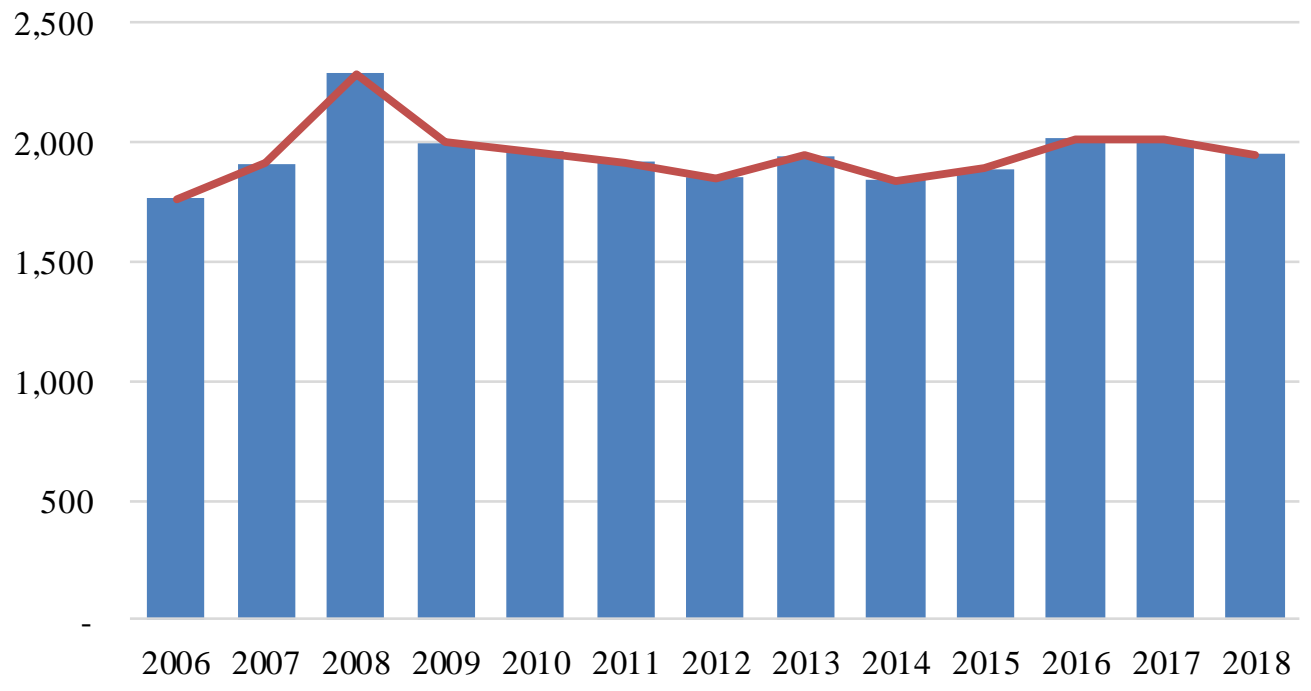

Fig.2: Flying Fish Catching Efforts in Makassar Strait Waters in 2006-2018

Catching efforts on fly fishing in the Makassar Strait waters tend to decline even though in several years there has been an increase. The decrease in fishing efforts occurred in 2008 until 2014, which amounted to 2,287 to 1,841 fishing units.

\subsection{Catch Per Unit Effort (CPUE)}

CPUE is one indicator of sustainable fisheries management. The general pattern of a fishery that is exploited which experiences overfished indicators is that the increase in total effort is followed by an increase in catches which is then followed by a decrease in catch per unit effort (CPUE). Catch per unit effort or Catch Per Unit Effort (CPUE) is a number that describes the comparis on between catches per unit of effort or effort. 
Catch Per Unit Effort (CPUE) for flying fish varies greatly each year. In several years several fishing gears were no longer used. The reason is that productivity has decreased so that it is necessary to use other fishing gear that is more effective and efficient for catching flying fish, especially in the Makassar Strait.

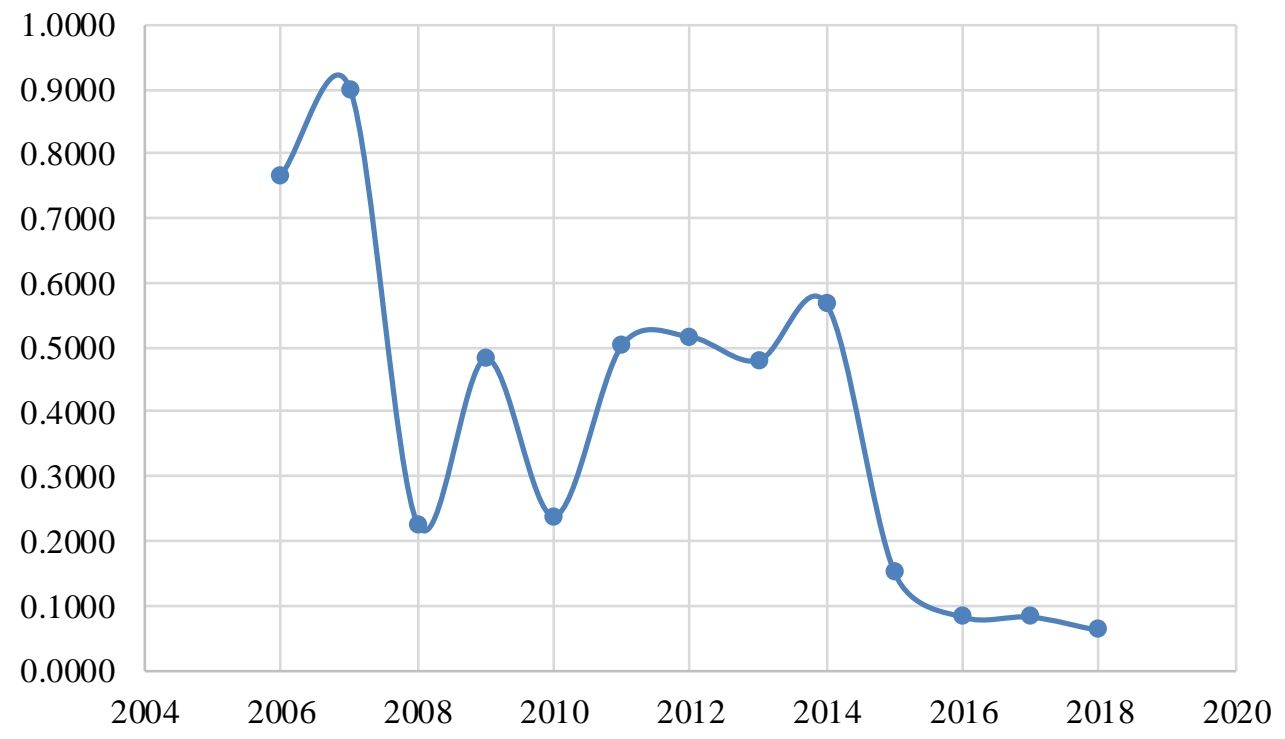

Fig.3: CPUE Resources for Flying Fish in the Makassar Strait in 2006-2018

See the CPUE value above, which number starts to decrease every year. If seen the above phenomenon is very worrying by the opinion of [18] that the CPUE value can be used to see the ability of the resource if it is continuously exploited. A declining CPUE value can indicate that the resource potential is unable to produce more even though the effort is increased.

\subsection{Relations CPUE and Effort}

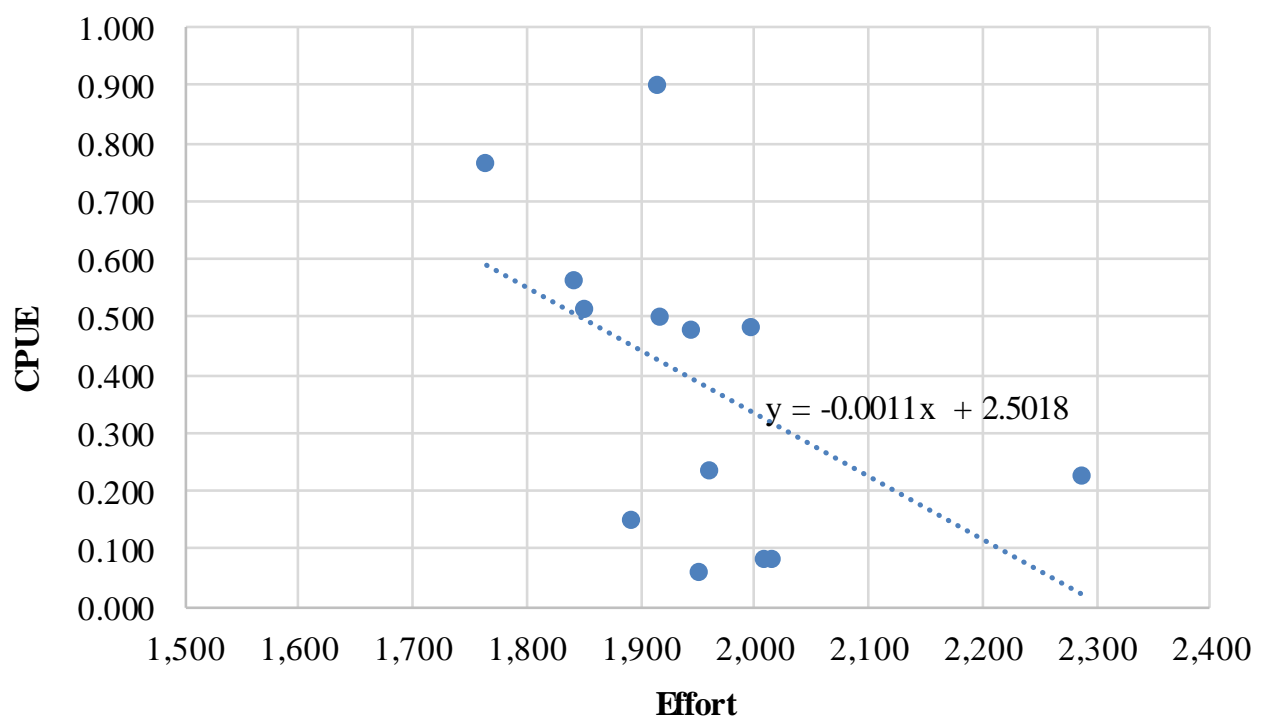

Fig.4: Relationship between CPUE and Fish Flying Efforts in the Makassar Strait

The relationship between CPUE and Effort on efforts to fly fishing in the Makassar Strait in the graph above shows a reciprocal relationship. This means that the increase in flying fishing efforts has caused CPUE to decline. From this equation it can be seen that the value of the slope that is negative indicates the CPUE and Effort relationship shows a negative relationship, the negative relationship is the relationship when the increase in a variable will cause a decrease in othervariables and conversely the increase in a variable will cause a decrease in othervariables [19]. This 
can be interpreted that an increase in effort will reduce the productivity of the catch (CPUE).

\subsection{Estimated Biological Parameters}

Biological parameters are one of the factors that greatly affect the survival of a marine organism, especially flying fish, because if one variable from biological parameters such as the carrying capacity of the environment does not match the needs, this will have an impact on the growth rate of flying fish.

Biological parameters that will be estimated include environmental carrying capacity (K), capture power coefficient $(\mathrm{q})$, and fish growth rate $(\mathrm{r})$. The estimation model used to estimate biological parameters is an estimation model developed by [17] or better known as the CYP model.

Estimation of biological parameters by the CYP method requires logarithmic input data from CPUE at time $t+1$ and logarithm CPUE at time $\mathrm{t}$ and input data Effort $\mathrm{t}$ at $\mathrm{t}$ and $\mathrm{t}+1$. To use OLS or regression, Ln CPUE $\mathrm{t}+1$ as $\mathrm{Y}$, Ln CPUE $\mathrm{t}$ as $\mathrm{X} 1$ and $\mathrm{Et}+\mathrm{Et}+1$ as $\mathrm{X} 2$ [20]. The estimation results from the three parameters presented in table 11 are useful for determining the level of production of sheets such as maximum sustainable yield (MSY), maximum economic yield (MEY) and open access (OA) conditions. This value can be seen in the following table:

Table 1. Results of Estimating Biological Parameters of Flying Fish

\begin{tabular}{clll}
\hline Number. & Biological Parameters & Estimated Results & Unit \\
\hline 1 & Fish Natural Growth Rate Constants (r) & 0.8651 & ton/year \\
2 & Capture Coefficient (q) & 0.00036 & ton/unit \\
3 & Environmental carrying capacity & 11,765 & ton \\
\hline
\end{tabular}

Source: Data Analysis Results processed, 2019.

Based on the data obtained as presented in Table 1. The constant growth rate of flying fish (r) is 0.8651 which means that flying fish can grow naturally without any interference from natural symptoms with a coefficient of 0.8651 tons or $865.1 \mathrm{Kg}$ per year. The capture coefficient (q) is 0.00036 , this means that the proportion of flying fish stocks that can be captured by a standard unit of fishing gear is 0,00036 tons. The catch coefficient value is influenced by the number of fishing gear used and the availability of flying fish resources in nature.

The waters carrying capacity constant $(\mathrm{K})$ is 11,765 , this indicates that the aquatic environment supports flying fish production of 11,765 tons per year from its biological aspects, including food abundance, population growth, and fish size. The greater the carrying capacity of water allows the increasing the number of flying fish production in the Makassar Strait waters.

\subsection{Estimated Economic Parameters}

\subsubsection{Estimated Input Cost}

The cost of using fly fish consists of fixed costs and variable costs. Fixed costs are costs that are not used up in one trip (trip). For fixed costs, the costs of depreciation of fishing equipment include boats, machines and gill net floats. While variable costs are costs that are used up for one trip (trip). Fisheries economic theory states that in open access fisheries where the cost of fishing is assumed to be comparable to business fishing business will continue to increase even though income per business unit decreases and ultimately income will decrease to equal costs incurred.
The overall estimation results of the cost of input flying fish in fly fishing business per trip are 1,318,861 or $137,985,212$ IDR per year. This input cost is dominated by oil fuel (diesel) which requires at least 90-150 liters of diesel per trip.

\subsubsection{Estimated Output Price}

In addition to the components of the capture costs required in this analysis also required price component data. The price component to be used in the analysis is the average price obtained from primary data or through direct interviews with fishermen and also secondary data from the Takalar District and Department of Maritime Affairs and Fishery of South Sulawesi Province with the 2006 time series up to 2018.

One problem in determining prices is the existence of abnormal price movements due to inflation. To overcome the abnormalities of the movement, adjustments were made by converting the nominal prices obtained to real prices. To convert nominal prices into real prices, the consumer price index (CPI) is used.

The estimated output price is obtained from the analysis of the nominal price which is then multiplied by the consumer price index. Then from that, the average real price is 6,200 per kilogram of flying fish.

\subsubsection{Estimated Discount Rate Level}

The parameter of the discount rate level refers to the investment interest rate and an inflation rate that applies in 2019. Based on data from Bank Indonesia for the value of the prevailing interest rate of 17.50 and the inflation rate of 
$3.32 \%$. To get the value of the piece of resource level estimated by the equation $d=\ln (1+i)$ where $i=$ the investment interest rate minus the inflation rate, so that the value of the piece of resource is obtained as $d=\ln (1+$ $(17.50 \%-3.32 \%)==2.72$.

3.7. Bioeconomic of Fish Resources Utilization in the Makassar Strait

Bioeconomic analys is of the use of flying fish in this study is estimated in 3 (three) management regime models, namely the Maximum Sustainable Yield (MSY) management regime, the Maximum Economic Yield (MEY) management regime and the Open Access (OA) management regime. The three management regime models are determined using analytical solving tools through the Micros oft Excel 2019 and Maple 18 program. The results of the bioeconomic optimization analysis of each flying fish management regime in this study are briefly presented in the following table.

Table 2. Results of Bioeconomic Optimization Analysis

\begin{tabular}{clrrr}
\hline \multirow{2}{*}{ Number } & \multicolumn{1}{c}{ Management Model } & $\begin{array}{c}\text { Effort (E) } \\
\text { (Unit) }\end{array}$ & Yield (Y) (Ton) & Biomass (X) (Ton) \\
\hline 1 & Maximum Sustainable Yield (MSY) & 1,215 & 2,545 & 5,882 \\
2 & Maximum Economic Yield (MEY) & 1,210 & 2,536 & 6,232 \\
3 & Open Access (OA) & 2,285 & 568 & 698 \\
4 & Actual & 1,944 & 1,604 & \\
\hline
\end{tabular}

Source: Data from the analysis, processed 2019

Based on the above table, the balance of MSY (Maximu m Sustainable Yield) in the production conditions is 2,545 tons per year, in the MEY (Maximum Economic Yield) balance it is 2,536 tons peryear and when the Open Access condition is obtained the production is 568 tons per year.
Of the three regimes above, it shows that in the Maximum Economic Yield condition it is advantageous when viewed from biological parameters and economic parameters when compared to the other two management regimes. To see more details, the picture follows.

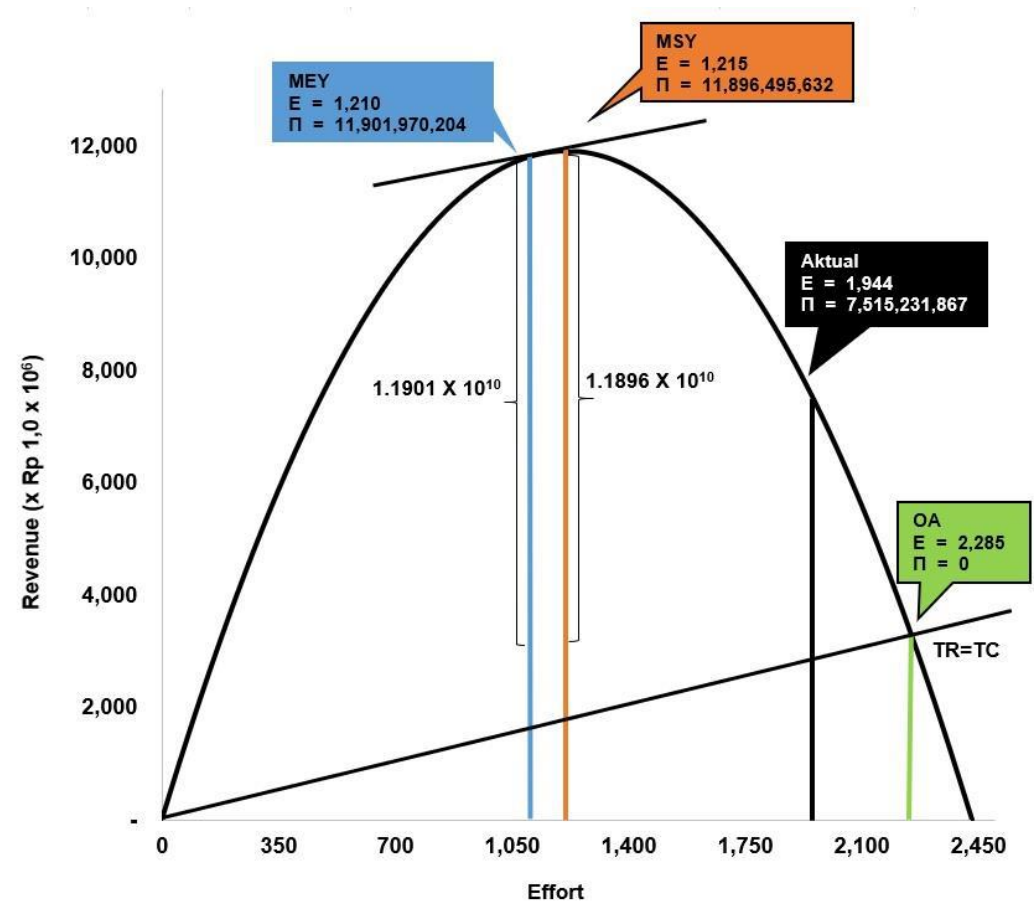

Fig.5: Bioeconomic Equilibrium offlying fish in the Makassar Strait

The maximum profit occurred during the MEY condition with an effort of 1,210 with an economic rent of $11,901,970,204$ IDR. When compared with the value of MSY with a smaller economic rent of 11,896,495,632 IDR. The difference in economic rent between MEY and MSY is around 5,474,572 IDR. While the Open Access (OA) condition does not have a rent value, in other words, the value of TR $=$ TC so that no profit is obtained at all.

\section{CONCLUSION}


The bioeconomic model consists of a management regime for Maximum Sustainable Yield (MSY), Maximum Economic Yield (MEY) and Open Access (OA). In the Maximum Sustainable Yield (MSY) regime the economic rent value of 11,896,495,281 IDR and the effort of 1,215, the Maximum Economic Yield (MEY) regime obtained the economic rent value of 11,901,970,205 IDR and an effort of 1,210, while the open-access management regime obtained an effort of 2,285 and not economic rent, is obtained because the value of costs and revenues obtained are of equal magnitude.

\section{REFERENCES}

[1] Indra, "Kajian Degradasi dan Depresiasi Sumberdaya Ikan di Provinsi Nanggroe Aceh Darussalam," Universitas Syiah Kuala, Banda Aceh, 2007.

[2] Parin N. V., Exocidae (Flyingfishes). In: CARPENTER, K.E., and V.H. NIEM(editors), FAO species identification guide for fishery purposes the living marine resources of the Western Central Pacific, Vol 4. Bony Fishes Part 2 (Mugilidae to Carangidae). Food and Agriculture Organization of the United Nations, Rome. p. 2162-2179., 1999.

[3] Clark C. W., Mathematical Bioeconomics: The Optimal Management of The Renewable Resources. Canada: John Wiley and Sons, 1985.

[4] Seijo D. O. J.C. and S. S., Fisheries bioeconomics: Theory, modeling, and management FAO Fisheries. Technical paper 368, ISBN 92-5-104045-1, 1998.

[5] Zainuddin, "Pengkajian Upaya Penangkapan Purse Seine dan Produksi Ikan Kembung (Rastrelliger spp) dengan Model Bioekonomi Linier Dinamik di Perairan Kabupaten Barru, Sulawesi Selatan (Skripsi).," Bogor: Institut Pertanian Bogor, 1994.

[6] Najamuddin, "Kajian Pemanfaatan Sumberdaya Ikan Lay ang (Decapterus spp) Berkelanjutan di Perairan Selat Makassar(Disertasi).,"Makassar: Universitas Hasanuddin, 2004.

[7] Baso A., "Pengelolaan Sumberdaya Perikanan Ikan Terbang (Cypsilurus spp) Berkelanjutan di Selat Makassar dan Laut Flores (Suatu Kajian Bio-TeknisSosial_Ekonomi) (Disertasi).," Makassar: Universitas Hasanuddin, 2004.

[8] Petersen E. H., C. J, and B. P., "Bioeconomics of Spiny Lobster Farming in Indonesia.," J. World Aquac. Soc., 2011.

[9] Najamuddin, A. Baso, and R. Arfiansy ah, "Bio-Economic Analyses of Coral Trout Grouper Fish in Spermonde Archipelago , Makassar, Indonesia," vol. 10, no. 2, pp. 247-264, 2016.

[10] Baso A., "Bioeconomic Analysis of Grouper Fish ( Plectropomus leopardus ) Utilization in Selayar Archipelago Regency," no. 05, 2016.

[11] Garcia S. M. and Chocrane K. L., "Ecosy stem Approach to Fisheries: A Review of Implementation guidelines.," ICES J. Mar. Sci., 2005.

[12] Sugiyono, Metodelogi Penelitian Kuantitatif, Kualitatif Dan $R \&$ D. Bandung: ALFABETA, 2013.

[13] Arikunto and Suharsimi, Prosedur Penelitian Suatu pendekatan Praktek. Jakarta: Rineka Cipta., 2010.

[14] Gulland J. A., Fish Stock Assessment (A Manual of Basic Methods). ChichesterNew York-Brisbane-Toronto.
Singapore: John Wiley and Sons. 223., 1991.

[15] Fox W. W., "An Exponential Surplus-Yield Model for Optimizing Exploited Fish Populations.," Trans. Am. Fish. Soc. 99 80-88, 1970.

[16] Schnute J., "Improved Estimates from the Schaefer Production Model: Theoretical Considerations.," J. Fish. Res. Board Canada, 34583-603, 1977.

[17] Clarke Y. S. \& P.P. P.R., "A Bioeconomic Analysis of the Northwestern Hawaiian Islands Lobster Fishery.," J. Mar. Resour. Econ. 7 115-140, 1992.

[18] King. M, "Fisheries Biology, Assesment and Management.," Fish. News Book. Gt. Britain., 1995.

[19] Santosa B. P. and Ashari, Analisis Statistik dengan Microsoft Excel \& SPSS. Yogy akarta: Andi Offset, 2005.

[20] Fauzi. A and Anna. Suzy, Pemodelan Sumberdaya Perikanan dan Kelautan. Jakarta: Gramedia Pustaka Utama, 2005. 